\title{
The Problems of Investigating Crime in Subsidized Fuel Oil Type Bio Solar
}

\section{Bibit Aris Yuliyanto*)}

*) Student of Master of Law, Universitas Islam Sultan Agung Semarang and The Indonesian National Police, email: beebitcapcus@gmail.com

Abstract. This study aims to analyze the role of investigators in handling crimes in the Oil and Gas / Subsidized Fuel Sector, especially the Bio-Solar Type in the Legal Area of the Central Java Regional Police and the obstacles faced and their solutions.

The method used by researchers is a sociological juridical legal approach and the specifications in this study include descriptive analytical. Primary data were obtained from field studies interviews with investigators in the jurisdiction of the Central Java Regional Police.

Based on the results of the study, it is concluded that the role of investigators in handling crimes in the Oil and Gas / Subsidized Fuel Sector, especially the BioSolar Type, is that they have carried out their duties in accordance with applicable regulations, from conducting investigations and investigations. Obstacles in Law Enforcement of the Crime of Misuse of Subsidized Fuel Type of Solar in the Central Java Regional Police, namely: a) lack of quality human resources; b) Lack of Facilities and Infrastructure; c) Difficulty in uncovering evidence; d) The amount of budget required in the Evidence Process. The solution is a) Organizing special learning activities for the Police; b) Fostering harmonious and kinship with the community, c) Forming a special team to spy on a place that is often used as a place for individuals who use subsidized fuel to buy diesel fuel.

Keywords: Investigator, investigation, Crime, Fuel Oil.

\section{Introduction}

In the life of the nation and state, security is a determining factor in the life of the nation and the state of implementing a sovereign and authoritative government, which is the main condition that supports the realization of a just, prosperous, prosperous and civilized life in a civil society system based on Pancasila and the Constitution of the Republic of Indonesia 1945. Domestically, the National Police carries out law enforcement efforts through the process of investigating and investigating criminal acts as regulated in Act No. 2 of 2002 concerning the Indonesian National Police. ${ }^{1}$

Oil and gas are natural resources controlled by the state and are a source of vital commodities that play an important role in the supply of fuel for industry, households and other basic necessities, which are needed in serving the needs of the general public both in poor countries and developing countries. And even in countries that have developed country status. ${ }^{2}$

\footnotetext{
${ }^{1}$ Ni Made Srinitri, Umar Ma'ruf, Progressivity Of Criminal Handling Fraud And Disease By The Directorate Of The General Criminal Researcher Of Central Java Regional Police (POLDA), Jurnal Daulat Hukum Volume 3 Issue 1, March 2020 ISSN: 2614-560X

${ }^{2}$ BPH Migas, 2005, Komoditas Bahan Bakar Minyak (BBM), Jakarta: BPH Migas RI
} 
Law in Indonesia is divided into two, namely public law and private or civil law. Public law is the law that regulates the public interest and regulates the relationship between the ruler and its citizens, while private law is the law that regulates the relationship between one person and another. In this case, criminal law is included in the category of public law. Based on this legal classification, several views see that criminal law and administrative law can be clearly separated, but the two legal rules are interrelated. Criminal law as public law has a close relationship with administration. Such is the close relationship between criminal law and other branches of law, especially in this case state administrative law, so that Wirjono Prodjodikoro states that: ${ }^{3}$ "The boundary signs between criminal law on the one hand and state administrative law on the other, lie in a sense of justice."

Act No. 22 of 2001 concerning Oil and Natural Gas (Migas) is further mentioned by the Oil and Gas Law, including one of the laws that regulates legal principles within the scope of state administrative law. This can be seen from the licensing regulations relating to the implementation of downstream business activities. Downstream business activities are business activities that are core or based on processing, transportation, storage and trading business activities. Various laws and regulations issued by the government must be enforceable and enforced in the event of a violation. The state, in particular the government, is responsible for maintaining the rules in the legislation. In enforcing these rules legal sanctions are used. One of the threats of punishment is criminal sanctions. The formulation of the Oil and Gas Law also contains criminal provisions. The criminal provisions are contained in chapter XI, namely Article 51, Article 52, Article 53, Article 54, Article 55, Article 56, Article 57, and Article 58.

One of the alleged cases of criminal action in the oil and natural gas sector, namely abusing the transportation and / or trading of fuel oil subsidized by the government Jo Participating in this act, the subsidiary carries out transportation without a transportation business license and / or keeps a storage business without a storage business license, as referred to in Article 55 of the primer. Republic of Indonesia Act No. 22 of 2001 Jo Article 55 paragraph (1) to 1e of the Criminal Code subsidiary to Article 53 letter b and / or letter c jo Article 23 paragraph (2) letter b, c Republic of Indonesia Act No. 22 of 2001 concerning oil and natural gas, which was carried out by the suspect MULYADI, SH Bin MUJI SUMARTO, address Jonalan Rt. 001 Rw. 003 Village of Cawas Sub District Head of district of Klaten.

The importance of criminal sanctions in the enforcement of state administrative law by criminal law can be seen from Logeman's opinion quoted by Soehardjo that: 4 "The state administrative law provides principles that guide the government's participation

\footnotetext{
${ }^{3}$ Wirjono Prodjodikoro, 2003, Asas-Asas Hukum Pidana di Indonesia, Bandung: Refika Aditama, p. 17-18. ${ }^{4}$ THRanidajita, 1994, Eksistensi Sanksi Pidana dalam hukum administrasi Negara, Semarang: Faculty of Law Undip, p. 21.
} 
in socio-economic relations, namely rules that the government itself is sanctioned with in case of violations."

This also creates ambiguity in the settlement of cases of violations of administrative law that contain criminal sanctions. Will it be carried out by law enforcement officials. This situation will of course lead to legal uncertainty and uncertainty for the community. Particularly in cases of fuel hoarding by gas stations, there are different legal handling applications. There are gas station owners who are handled through criminal law enforcement or through state administrative law. And what is the role of BPH Migas in the cases of oil fuel hoarding.

One of the alleged cases of criminal action in the oil and natural gas sector, namely abusing the transportation and / or trading of fuel oil subsidized by the government Jo Participating in this act, the subsidiary carries out transportation without a transportation business license and / or keeps a storage business without a storage business license, as referred to in Article 55 of the primer. Republic of Indonesia Act No. 22 of 2001 Jo Article 55 paragraph (1) to 1e of the Criminal Code subsidiary to Article 53 letter b and / or letter c jo Article 23 paragraph (2) letter b, c Republic of Indonesia Act No. 22 of 2001 concerning oil and gas Bumi, conducted by the suspect MULYADI, SH Bin MUJI SUMARTO, that on Friday, November 30 2018, from 13.30 WIB until finished officers from Unit 2 / Subdit 4 Dit Reskrimsus Polda Central Java, had found and visited the storage of diesel fuel types at the address of Doyo Village Ngawonggo Dist. Ceper Reg. Klaten. In the warehouse, the officers found that there was diesel fuel stored in several Kempu (diesel storage places) and alkon (diesel fuel suction device).

Based on the background of the problem above, the following problems can be formulated: What is the role of investigators in handling crimes in the Oil and Gas Sector / Subsidized Fuel, especially the Bio-Solar Type in the Legal Area of the Regional Police of Central Java? What obstacles do investigators face in handling crimes in the Oil and Gas / Subsidized Fuel Sector, especially the Bio-Solar Type in the Legal Territory of the Regional Police of Central Java and what is the solution?

\section{Research Methods}

This research uses a juridical sociological / socio legal research approach, where in this research the technical steps taken follow the social science assessment patterns, especially sociology and law. ${ }^{5}$ Sociological juridical research is research that tends to be qualitative in nature, based on primary data. As for the sources and types of data in this study are primary data obtained from field studies interviews with Central Java Police investigator. And secondary data obtained from literature studies related to law

\footnotetext{
${ }^{5}$ Soekanto Soerjono, 1986, Pengantar Penelitian Hukum, Jakarta: UI Press, p. 60
} 
enforcement theory. The research specification is analytical descriptive. The method used to analyze the data in this study is qualitative juridical

\section{Results And Discussion}

\subsection{The Role Of Investigators In Handling Crimes In The Oil And Gas / Subsidized Fuel Sector, Especially The Bio-Solar Type In The Legal Territory Of The Regional Police Of Central Java}

In carrying out their duties in handling criminal cases, investigators and the public prosecutor have established functional and institutional relationships between investigators and public prosecutors. The functional and institutional relationship between the criminal justice component of the Police and the Prosecutor's Office has been established since the notification of the commencement of the investigation. ${ }^{6}$ As is known, the Criminal Code ( $W V S)$ in effect in Indonesia so far has not formulated general guidelines for punishment governing judge forgiveness. The formula of rechterlijk pardon principle in the criminal guidelines is important because it is appropriate for the flexibility / elasticity and modification of punishment which comes from the values of religious wisdom. ${ }^{7}$

Realizing that oil and natural gas are the livelihoods of many people, the Indonesian government has long been trying to protect the country's natural resources. This can be seen in the existence of Act No. 32 of 2009 concerning Environmental Protection and Management, which is a systematic and integrated effort carried out to preserve environmental functions and prevent environmental pollution and / or damage which includes planning, utilization, control, maintenance, supervision and law enforcement. ${ }^{8}$ And several products of laws and regulations governing oil and natural gas, starting in 1960, the Indonesian government at that time issued Law No. 44 of 1960 which mandated that the exploitation of oil and gas mining be carried out only by state companies. Then the New Order government on September 15, 1971 issued Act No. 8 of 1971 which stated that PERTAMINA (the State Oil and Gas Mining Company) was the only state company that had the right to manage oil and natural gas in Indonesia. ${ }^{9}$

\footnotetext{
${ }^{6}$ Aris Sophian, Umar Ma'ruf, Fulfillment Of Restitution Rights In The Level Of Investigation In The Big Semarang City Resort Police In Beating Criminal Case, Jurnal Daulat Hukum Volume 3 Issue 2, June 2020 ISSN: 2614-560X

${ }^{7}$ Sri Endah Wahyuningsih, 2018, Model Pengembangan Asas Hukum Pidana Dalam KUHP Berbasis Nilainilai Ketuhanan Yang Maha Esa, Semarang: Fastindo, p. 128

${ }^{8}$ Zulfikar Jayakusuma, 2011, Arti Penting Lingkungan Hidup Strategis Dalam Perlindungan Dan Pengelolaan Lingkungan Hidup Di Indonesia, Journal of Legal Studies, p. 144.

${ }^{9}$ Hasan Teuku H. Muhammad, 1985, Sejarah Perjuangan Perminyakan Dan Gas Bumi, Jakarta: Sari Pinang Sakti Foundation, p. 40.
} 
Based on an interview with Dwi Edy Purnomo, S.Pd., $\mathrm{MH}^{10}$. as the investigator of the alleged oil and gas crime, namely abusing the transportation and / or trading of fuel oil subsidized by the government, Jo Participating in the act, the subsidiary carried out the transportation without a transportation business license and or stored without a storage business license, as referred to in the primary article 55 of Republic of Indonesia Act No. 22 of 2001 in conjunction with Article 55 paragraph (1) to 1e of the Criminal Code, subsidiary to Article 53 letter $b$ and / or letter $c$ in conjunction with Article 23 paragraph (2) letter b, c of RI Act No. 22 of 2001 regarding oil and natural gas, which was carried out by the suspect MULYADI, SH Bin MUJI SUMARTO.

The role of investigators in handling crimes in the Oil and Gas / Subsidized Fuel Oil Sector, especially the Bio-Solar Type in the Legal Territory of the Central Java Regional Police, includes: Earth; b) Examining persons or entities suspected of committing criminal acts in Oil and Gas business activities; c) Search places and / or facilities suspected of committing criminal acts in Oil and Gas business activities; d) Checking Oil and Gas business activities facilities and infrastructure and suspending the use of equipment suspected of being used to commit criminal acts; e) Sealing and / or confiscating Oil and Gas business activity tools used to commit a criminal act as evidence; f) Bring in the necessary experts in connection with the examination of criminal cases in Oil and Gas business activities; g) To stop investigations of criminal cases in Oil and Gas business activities

\subsection{Obstacles Faced By Investigators In Handling Crimes In The Oil And Gas / Subsidized Fuel Sector, Especially The Bio-Solar Type In The Legal Territory Of The Regional Police Of Central Java And Their Solutions}

Case of Misuse and / or Commercial Transportation of Subsidized Oil Fuel Types of Solar is a violation of Article 53 Jo 55 of Act No. 22 Of 2001 concerning Oil and Gas, evidence of government subsidized diesel is as stated in the Presidential Regulation of the Republic of Indonesia Number 55 of 2005 In conjunction with Presidential Regulation of the Republic of Indonesia Number 9 of 2006, then for the price of each city or district it refers to these regulations and then it is stated in the Decree of the respective City or Regency Government, then the juridical analysis must meet the following elements: ${ }^{11}$

- Everyone is a punishable offender;

- Misusing commerce and or transportation;

- Subsidized diesel fuel;

\footnotetext{
${ }^{10}$ Results of an interview with Dwi Edy Purnomo, S.Pd., $\mathrm{MH}$ as an investigator in the jurisdiction of the Central Java Regional Police, on July 15 2020, 11.15 WIB

${ }^{11}$ Article 53 Jo 55 of Act No. 22 Of 2001 Concerning Oil and Gas, State Gazette of the Republic of Indonesia Of 2001 Number 136
} 
- Doing trade in diesel fuel without permission.

The obstacles faced by investigators in handling crimes in the Oil and Gas / Subsidized Fuel Sector, especially the Bio-Solar Type in the Legal Territory of the Regional Police of Central Java include:

- Human; In terms of the quality of law enforcement officers, the existing Human Resources are still considered not of high quality. This is due to the lack of knowledge of the apparatus themselves, such as the lack of training and skills regarding certain crimes.

- Lack of facilities and infrastructure; The facility and infrastructure factor is an obstacle faced by the police.

- The difficulty of uncovering evidence; Police officers cannot simply arrest people who are suspected of having carried out transactions or practices of misuse of this type of subsidized fuel because they must have sufficient evidence to arrest them. In this case the police must be careful in taking samples of evidence in cases of misuse of subsidized diesel fuel.

- The places for buying and selling of this type of diesel fuel are mobile; Every person who abuses subsidized fuel of this type of diesel will not carelessly buy or sell this type of diesel fuel. .

- The amount of budget needed in the Proving Process; Misuse of subsidized diesel fuel.

Based on Dwi Edy Purnomo, S.Pd., $\mathrm{MH}^{12}$ as the investigator, that he said there were several efforts made by the police in overcoming the criminal act of misuse of subsidized fuel, namely:

- Organizing special learning activities for the Police.

- Fostering a harmonious and family-friendly relationship with the community; In this case, the relationship between the police and the community is less harmonious in that the community is afraid of the police. This kind of thinking needs to be eliminated in society by the way the Police strengthen ties and embrace the community to be close and make the Police a friend, not a person to be feared.

- Forming a special team to spy on a place that is often used as a place for people who use subsidized fuel to buy diesel fuel

- Ambush

After the information needed is deemed sufficient and other supporting matters are considered available, both the evidence is sufficient and law enforcement officials see for themselves that there has been a criminal act of misuse of subsidized fuel, then they can ambush the perpetrator because it is feared that the perpetrator will run

\footnotetext{
${ }^{12}$ Results of an interview with Dwi Edy Purnomo, S.Pd., $\mathrm{MH}$ as an investigator in the jurisdiction of the Central Java Regional Police, on July 15 2020, 11.15 WIB
} 
away. In this case, for example, the police disguised themselves as businessmen who would buy diesel fuel at a low price from the perpetrator.

\section{Closing}

\subsection{Conclusion}

The role of investigators in handling crimes in the Oil and Gas / Subsidized Fuel Sector, especially the Bio-Solar Type in the Legal Territory of the Central Java Regional Police are: a) Checking the correctness of reports or information received regarding criminal acts in Oil business activities and Natural gas; b) Examining persons or entities suspected of committing criminal acts in Oil and Gas business activities; c) Search places and / or facilities suspected of committing criminal acts in Oil and Gas business activities; d) Checking Oil and Gas business activities facilities and infrastructure and suspending the use of equipment suspected of being used to commit criminal acts; e) Sealing and / or confiscating Oil and Gas business activity tools used to commit a criminal act as evidence; f) Bring in the necessary experts in connection with the examination of criminal cases in Oil and Gas business activities; g) Stop investigations of criminal cases in Oil and Gas business activities. Obstacles in Law Enforcement of the Crime of Misuse of Subsidized Oil Fuel in the Central Java Regional Police, namely, firstly there is a lack of quality of human resources, secondly the factor of inadequate facilities and infrastructure, thirdly the difficulty of uncovering evidence, the four points of purchase and sale of transactions misuse of subsidized diesel fuel is mobile and the fifth is the amount of budget required by the police in the process of proving a case using expert witnesses. Efforts to overcome obstacles in the Law Enforcement of the Abuse of Subsidized Oil Fuel in the Central Java Regional Police are holding special learning activities for the police, complementing existing facilities and infrastructure, fostering harmonious and familial relationships with the community, forming a special team to spy on a place that is often used as a place for people who abuse subsidized fuels

\subsection{Suggestion}

It is hoped that in the jurisdiction of the Central Java Regional Police, especially the Rector of Special Criminal Investigation, which in this case is the law enforcer who is in the jurisdiction of the Central Java Regional Police to be firm and quickly tackle the misuse of subsidized diesel fuel in the Central Java Regional Police and in the process to put forward investigative interests, namely in accordance with the provisions applicable in this Republic. The rapid development of technology today will also affect the development of types and patterns of crime. The crime of misuse of subsidized fuel is a well-known conventional crime. Thus, it should be necessary to do things that can 
make law enforcers reach the crime of misuse of subsidized fuel in any model, pattern, and mode. The need to increase public awareness of the law. In this case the full role of the community is needed to assist the police.

\section{Bibliography}

Journal

Aris Sophian, Umar Ma'ruf, "Fulfillment Of Restitution Rights In The Level Of Investigation In The Big Semarang City Resort Police In Beating Criminal Case", in Jurnal Daulat Hukum Volume 3 Issue 2, June 2020 ISSN: 2614-560X

Ni Made Srinitri, Umar Ma'ruf, "Progressivity Of Criminal Handling Fraud And Disease By The Directorate Of The General Criminal Researcher Of Central Java Regional Police (POLDA)", in Jurnal Daulat Hukum Volume 3 Issue 1, March 2020 ISSN: 2614-560X

Books

BPH Migas, 2005, Komoditas Bahan Bakar Minyak (BBM), Jakarta: BPH Migas RI

Hasan Teuku H. Muhammad, 1985, Sejarah Perjuangan Perminyakan Dan Gas Bumi, Jakarta: Sari Pinang Sakti Foundation

Article 53 Jo 55 of Act No. 22 Of 2001 Concerning Oil and Gas, State Gazette of the Republic of Indonesia Of 2001 Number 136

Soekanto Soerjono, 1986, Pengantar Penelitian Hukum, Jakarta: UI Press

Sri Endah Wahyuningsih, 2018, Model Pengembangan Asas Hukum Pidana Dalam KUHP Berbasis Nilai-nilai Ketuhanan Yang Maha Esa, Semarang: Fastindo

THRanidajita, 1994, Eksistensi Sanksi Pidana dalam hukum administrasi Negara, Semarang: Faculty of Law Undip

Wirjono Prodjodikoro, 2003, Asas-Asas Hukum Pidana di Indonesia, Bandung: Refika Aditama

Zulfikar; Jayakusuma, 2011, Arti Penting Lingkungan Hidup Strategis Dalam Perlindungan Dan Pengelolaan Lingkungan Hidup Di Indonesia, Journal of Legal Studies 